\title{
Phenylephrine protects neonatal rat cardiomyocytes from hypoxia and serum deprivation-induced apoptosis
}

\author{
H Zhu ${ }^{\star, 1}$, S McElwee-Witmer ${ }^{1}$, M Perrone ${ }^{1}, \mathrm{KL} \mathrm{Clark}^{1}$ and \\ A Zilberstein ${ }^{1}$ \\ Department of Cardiovascular Biology, Rhone-Poulenc Rorer Research and \\ Development, Collegeville, PA 19426, USA \\ * Corresponding author: H Zhu, Collateral Therapeutics, Inc. Research Center, \\ Suite 100, 11025 Roselle Street, San Diego, CA 92121, USA. Fax: (858) 404- \\ 9350; E-mail: hzhu@collateralthx.com
}

Received 21.1.00; revised 30.3.00; accepted 11.5.00

Edited by CJ Thiele

\begin{abstract}
Previous studies have shown that $\alpha$-adrenergic activation reduces myocardial damages caused by ischemia/reperfusion. However, the molecular mechanisms of how $\alpha$-adrenergic activation protects the myocardium are not completely understood. The objective of this study was to test the hypothesis that $\alpha$-adrenergic activation protects the myocardium by, at least in part, inhibiting apoptosis in cardiomyocytes. The current data has shown that apoptosis in neonatal rat cardiomyocytes, induced by $24 \mathrm{~h}$ treatment with hypoxia $\left(95 \% \mathrm{~N}_{2}\right.$ and $\left.5 \% \mathrm{CO}_{2}\right)$ and serum deprivation, was inhibited by co-treatment with phenylephrine. Pre-treatment with phenylephrine for $24 \mathrm{~h}$ also protected cardiomyocytes against subsequent $24 \mathrm{~h}$ treatment with hypoxia and serum deprivation. Exposure of cardiomyocytes to phenylephrine for up to 9 days under normoxic conditions did not cause apoptosis. The phenylephrinemediated cytoprotection was blocked by an $\alpha$-adrenergic antagonist, phentolamine. $\beta$-adrenergic activation with isoproterenol did not protect cardiomyocytes against hypoxia and serum deprivation-induced apoptosis. Under hypoxic conditions, phenylephrine prevented the down-regulation of $\mathrm{Bcl}-2$ and $\mathrm{Bcl}-\mathrm{X}$ mRNA/protein and induced hypertrophic growth. Phenylephrine-mediated protection was abrogated by the phosphatidylinositol 3-kinase (PI 3-kinase) inhibitor wortmannin and was mimicked by the caspase- 9 peptidic inhibitor LEHD-fmk. These results suggest that $\alpha$-adrenergic activation protects cardiomyocytes against hypoxia and serum deprivation-induced apoptosis through regulating the expression of mitochondrion-associated apoptosis regulatory genes, preventing activation of mitochondrial damage-induced apoptosis pathway (cytochrome C-caspase-9), and activating hypertrophic growth. Cell Death and Differentiation (2000) 7, 773-784.
\end{abstract}

Keywords: apoptosis; adrenergic; cardiomyocytes; hypertrophy; ischemia

Abbreviations: ANF, atrial natriuretic factor; ISO, isoproterenol; LIF, leukemia inhibitory factor; MM, minimal medium; NO, nitric oxide; PARP, poly-adenyl ribose transferase; PE, phenylephrine; PHE, phentolamine; PI, posphoinositol; PM, plating medium

\section{Introduction}

Sustained ischemia and reperfusion cause a series of damages to the myocardium, including death of cardiomyocytes by the mechanisms of necrosis and apoptosis. ${ }^{1-5}$ Since the majority of adult cardiomyocytes are postmitotic, death of cardiomyocytes caused by ischemia and reperfusion leads to loss of cardiac muscle mass, formation of non-contractile fibrotic tissues and thereby decreases in cardiac output. ${ }^{6-8}$ However, repeated short term treatment with ischemia and reperfusion (preconditioning) protects the myocardium from subsequent sustained ischemia and reperfusion, suggesting that preconditioning activates protective mechanisms. ${ }^{9-11}$ Further studies have shown that $\alpha$-adrenergic activation is a part of preconditioning-activated protection in the myocardium. ${ }^{12-14}$ Not only is the myocardial $\alpha$-adrenergic activity elevated during the ischemia and reperfusion preconditioning, but also the preconditioning-activated protection can be mimicked by administration of an $\alpha$-adrenergic agonist, phenylephrine, prior to sustained ischemia and reperfusion. However, the molecular mechanisms by which $\alpha$-adrenergic activation protects the myocardium from sustained ischemia and reperfusion are not completely understood.

A recent report has shown that $\alpha$-adrenergic activation protects the myocardium possibly by inhibiting ischemia and reperfusion-induced apoptosis in the myocardium. ${ }^{15}$ In that study, however, it is not completely clear whether ischemia/ reperfusion-induced apoptosis in cardiomyocytes is inhibited directly by $\alpha$-adrenergic activation. On the other hand, $\alpha$ adrenergic activation does seem to protect isolated cardiomyocytes from cAMP-induced apoptosis. ${ }^{16}$ It has been shown that $\alpha$-adrenergic stimulation leads to activation of PI 3-kinase in both cardiac and smooth muscle cells ${ }^{17,18}$ and active PI 3-kinase can protect cardiomyocytes from apoptosis by activating Akt- 1 kinase. ${ }^{19}$ Active Akt- 1 inhibits cytochrome C-, released from damaged mitochondria, induced activation of caspase- 9 by phosphorylation. ${ }^{20}$ Although it has been demonstrated that active caspase- 9 triggers activation of downstream apoptosis cascade in nonmuscle cells. ${ }^{21}$ its involvement in hypoxia- and serum deprivation-induced cardiomyocyte apoptosis is not clear.

Since hypoxia and serum deprivation induce apoptosis in isolated neonatal rat cardiomyocytes, ${ }^{22-25}$ the current studies were designed to test whether hypoxia and serum deprivation induced-apoptosis in isolated cardiomyocytes can be inhibited by $\alpha$-adrenergic stimulation. The data in this study shows that phenylephrine protects cultured neonatal rat cardiomyocytes from hypoxia (95\% $\mathrm{N}_{2}+5 \%$ $\mathrm{CO}_{2}$ ) and serum starvation-induced apoptosis. Phenylephrine mediates this cytoprotection by $\alpha$-adrenergic receptor stimulation since phenylephrine-mediated protection can be 
blocked by an $\alpha$-adrenergic antagonist phentolamine. $\beta$ Adrenergic activation by isoproterenol, however, does not protect cardiomyocytes from hypoxia and serum deprivation. Under normoxic conditions, exposure of cardiomyocytes to phenylephrine for up to 9 days does not result in apoptosis whereas in the absence of phenylephrine and serum, cardiomyocytes start undergoing apoptosis on the second day. Phenylephrine not only inhibits the decrease in the ratios of $\mathrm{Bcl}-2$ :BAX and $\mathrm{Bcl}-\mathrm{X}: \mathrm{BAX}$ mRNA/protein but also induces hypertrophy under hypoxic conditions. In addition, phenylephrine-mediated protection is abrogated by co-treatment with the PI 3-kinase inhibitor wortmannin and mimicked by the caspase- 9 peptidic inhibitor LEHDfmk. Thus, $\alpha$-adrenergic activation may protect cardiomyocytes by maintaining mitochondrial integrity, preventing activation of the mitochondrial damage-induced apoptosis pathway (cytochrome C/caspase-9), and activating hypertrophic growth.

\section{Results \\ Phenylephrine inhibits hypoxia and serum deprivation-induced apoptosis in cultured neonatal rat cardiomyocytes}

To determine the effects of $\alpha$-adrenergic activation on cardiomyocyte apoptosis, cultured neonatal rat cardiomyocytes were induced to undergo apoptosis by $24 \mathrm{~h}$ treatment with a combination of hypoxia $\left(95 \% \mathrm{~N}_{2}+5 \% \mathrm{CO}_{2}\right)$ and serum deprivation in the presence or absence of $50 \mu \mathrm{M}$ phenylephrine. As controls, cardiomyocytes cultured under normoxic conditions either with or without serum for $24 \mathrm{~h}$ were included. Apoptosis in these cardiomyocytes was assessed by a number of criteria. First, the morphology of cardiomyocytes was examined by microscopic analysis of phase images (Figure 1A,D,G,J) and fluorescent images of cardiomyocytes from the same fields, following a dual staining with an antibody against muscle specific $\alpha$-actinin (Figure $1 \mathrm{~B}, \mathrm{E}, \mathrm{H}, \mathrm{K}$ ) and Heochst 33258 (Figure 1C,F,I,L). As reported previously, cardiomyocytes which were treated with hypoxia and serum deprivation for $24 \mathrm{~h}$ displayed a series of apoptotic morphological changes, e.g. cell shrinkage (Figure 1D,E, black and white arrows respectively), sarcolemma blebbing (Figure 1D,E, black and white arrows respectively), and nuclear condensation (Figure 1F, white arrows). These morphologic properties characteristic of apoptosis were not observed in the majority of control cardiomyocytes cultured under normoxic conditions, either with (Figure $1 A-C)$ or without serum (Figure 1G-I). The above apoptotic morphologic changes, induced by hypoxia and serum deprivation, were prevented by co-treatment with $50 \mu \mathrm{M}$ phenylephrine (Figure $1 \mathrm{~J}-\mathrm{L}$ ). Cardiomyocytes cultured under hypoxia and serum deprivation for $24 \mathrm{~h}$ did not show spontaneous beating as the control cardiomyocytes do. However, cardiomyocytes co-treated with $50 \mu \mathrm{M}$ phenylephrine under hypoxia and serum deprivation displayed synchronized spontaneous beating as the control cardiomyocytes (data not shown). The above results suggest that neonatal cardiomyocytes are protected by phenylephrine against hypoxia and serum deprivation-induced apoptosis.
To confirm that phenylephrine protects cardiomyocytes against hypoxia and serum deprivation-induced apoptosis, the activity of a major apoptosis executioner, caspase-3, was measured in cardiomyocytes treated with hypoxia and serum deprivation in the presence or absence of $50 \mu \mathrm{M}$ phenylephrine. As described in the Materials and Methods section, a fluorogenic caspase-3 specific substrate, DEVDAFC, was utilized to quantify caspase-3 activity in whole cell extracts prepared from cardiomyocytes. The endogenous caspase-3 was activated by hypoxia and serum deprivation, with its peak activity at approximately the $3 \mathrm{~h}$ time point (Figure 2A). Caspase-3 activation by hypoxia and serum deprivation was inhibited by cotreatment with $50 \mu \mathrm{M}$ phenylephrine. Suppression of hypoxia and serum deprivation-triggered caspase- 3 by phenylephrine was further confirmed by the results of Western blot analysis. As shown in Figure 2B, the endogenous caspase-3 substrate. PARP (poly-adenyl ribose transferase), was degraded from a $120 \mathrm{kD}$ protein to an $85 \mathrm{kD}$ protein in cardiomyocytes treated with hypoxia and serum deprivation for $3 \mathrm{~h}$. In both phenylephrinetreated and control cardiomyocytes, only $120 \mathrm{kD}$ PARP protein was detected.

An apoptosis hallmark, triggered by caspase-3 activation, is genomic DNA fragmentation: genomic DNA degraded into the lengths of multiple mononucleosomes $(n \times 180 \mathrm{bp})$, observed as ladders on agarose gels. Therefore, genomic DNA fragmentation was analyzed by agarose gel electrophoresis. As shown in Figure 3, genomic DNA from cardiomyocytes cultured in the presence of both oxygen and serum was detected as a single high molecular weight band on an agarose gel, suggesting that there was no significant DNA fragmentation in these cardiomyocytes.

However, genomic DNA from cardiomyocytes cultured under normoxic conditions at the absence of serum for $24 \mathrm{~h}$ displayed a faint 'DNA ladder' on an agarose gel, as a result of fragmentation. The signal of 'DNA ladder' was much stronger with genomic DNA from cardiomyocytes treated with a combination of hypoxia and serum deprivation for $24 \mathrm{~h}$. Genomic DNA fragmentation induced by hypoxia and serum deprivation was almost completely inhibited by $50 \mu \mathrm{M}$ phenylephrine. Taken the above data together, neonatal cardiomyocytes are protected by phenylephrine against hypoxia and serum deprivationinduced apoptosis.

\section{Phenylephrine protects cardiomyocytes through $\alpha$-adrenergic receptor stimulation}

To confirm that phenylephrine protects cardiomyocytes through $\alpha$-, but not $\beta$-adrenergic stimulation, it was determined whether the phenylephrine-mediated cytoprotection could be inhibited by an $\alpha$-adrenergic antagonist, phentolamine. Cardiomyocytes were treated with hypoxia and serum deprivation for $24 \mathrm{~h}$ in the presence of both phentolamine (final 5, 15, and $45 \mu \mathrm{M}$ ) and phenylephrine (final $50 \mu \mathrm{M}$ ) and apoptosis was subsequently assessed by genomic DNA fragmentation. As shown in Figure 4A, inhibition of genomic DNA fragmentation by $50 \mu \mathrm{M}$ phenylephrine was abolished by phentolamine, indicating that phenylephrine protects cardio- 
$\mathbf{A}^{\prime}$
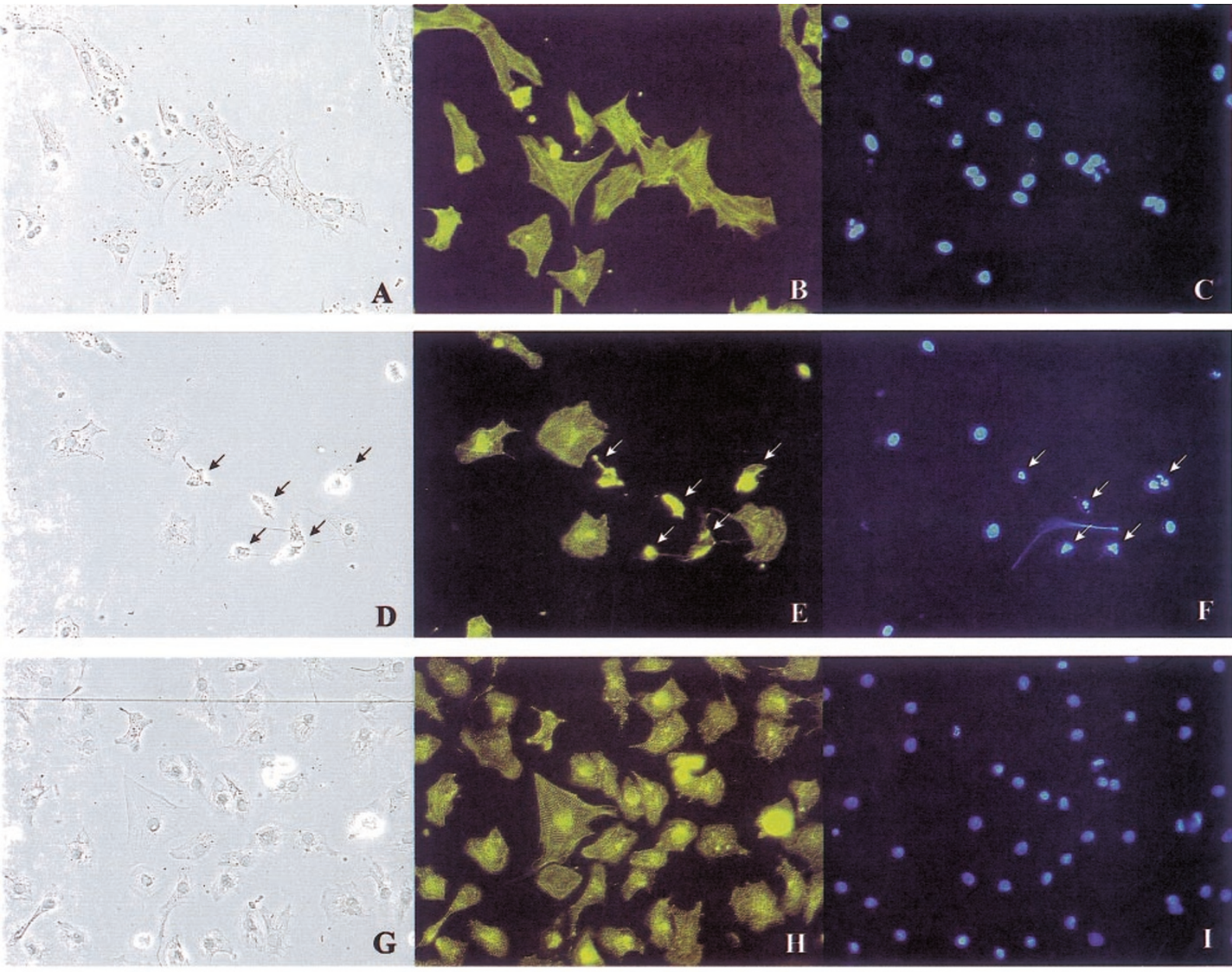

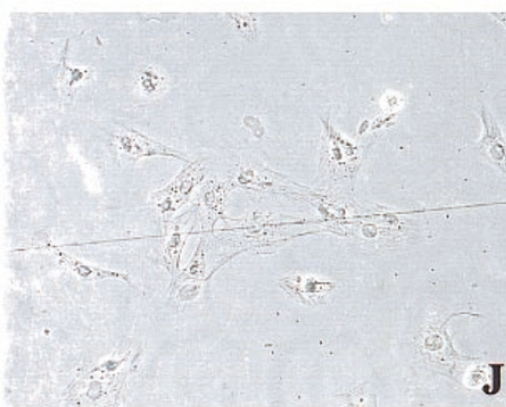

Phase

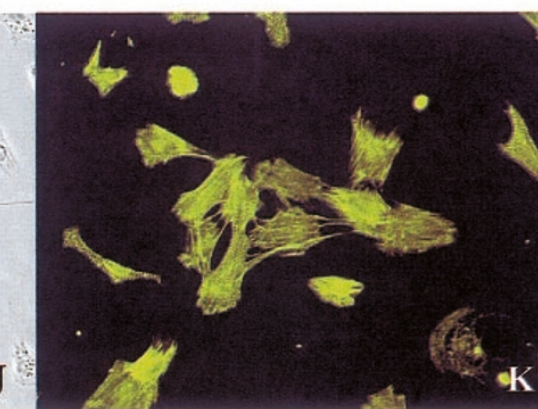

$\alpha$-Actinin

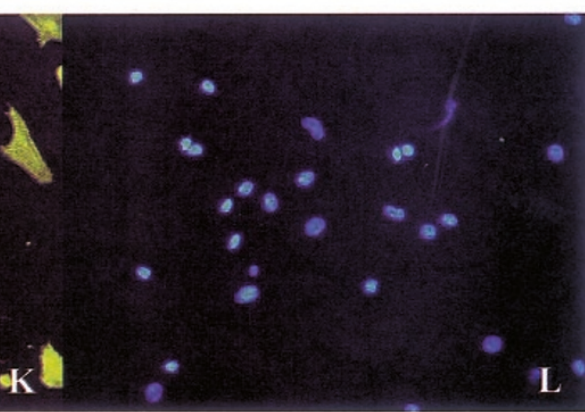

Hoechst33258

Figure 1 Phenylephrine inhibits hypoxia and serum deprivation-induced apoptotic morphological changes. Images of neonatal rat cardiomyocytes, cultured either under normal conditions (with both oxygen and serum, $\mathbf{A}-\mathbf{C})$, or under hypoxia $\left(95 \% \mathrm{~N}_{2}+5 \% \mathrm{CO}_{2}\right.$ ) and serum deprivation (D-F), or under normoxia with serum deprivation $(\mathbf{G}-\mathbf{I})$, or under hypoxia and serum deprivation in the presence of $50 \mu \mathrm{M}$ phenylephrine $(\mathbf{J}-\mathbf{L})$ for $24 \mathrm{~h}$, were examined for apoptotic changes. Left column: phase contrast images: middle column: images of immunofluorescent staining with an anti- $\alpha$-actinin antibody; right column: images of fluorescent staining with Hoechst33258. Magnification: $200 \times$

myocytes through $\alpha$-adrenergic stimulation. Under normoxic conditions, phentolamine had no affect on genomic DNA. Furthermore, genomic DNA fragmentation induced by $24 \mathrm{~h}$ treatment with hypoxia and serum deprivation was not inhibited by a $\beta$-adrenergic agonist, isoproterenol, at final concentrations of 50 and $100 \mu \mathrm{M}$ (Figure 4B).

\section{Phenylephrine alters the expression of apoptosis regulatory genes}

The expression of several apoptosis controlling genes in cardiomyocytes, e.g. the members of Bcl-2 family, are regulated in response to a variety of extracellular apoptotic 


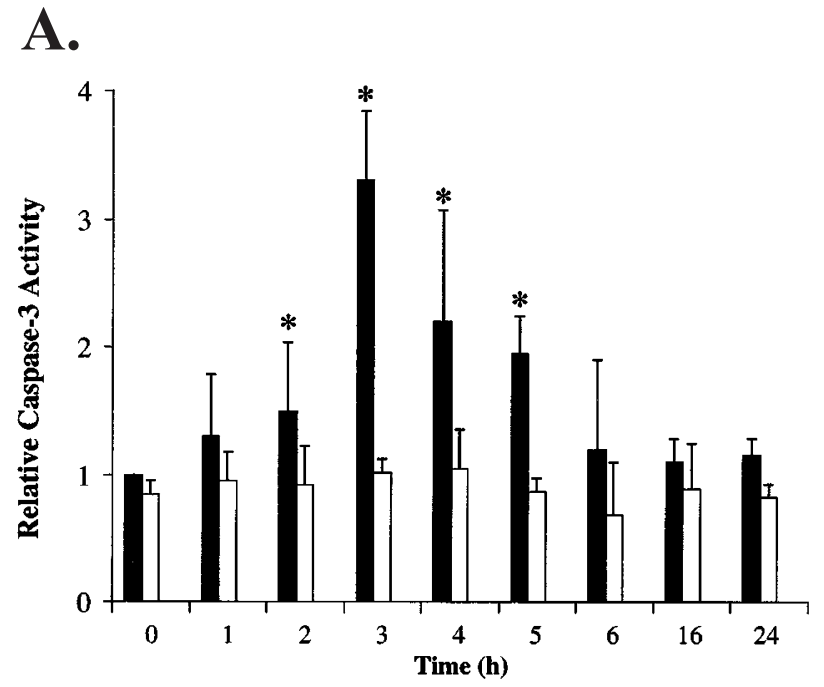

B.

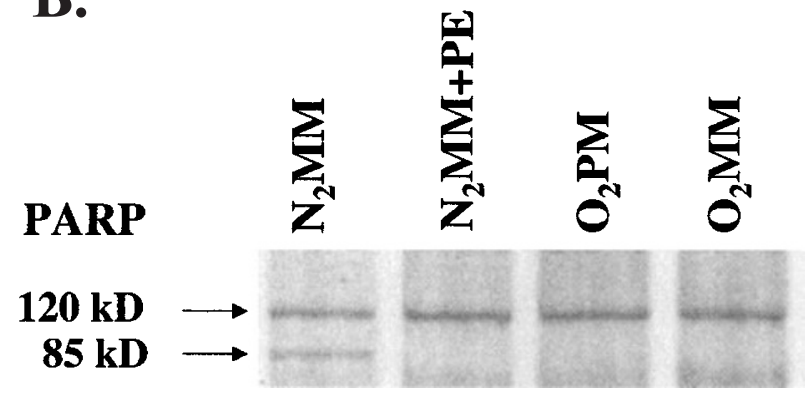

Figure 2 Phenylephrine suppresses hypoxia and serum deprivation-induced caspase-3 activation. (A) Cardiomyocytes were treated with hypoxia and serum deprivation for $0,1,2,3,4,5,6,16$, and $24 \mathrm{~h}$ in the presence (open bars) or absence (solid bars) of $50 \mu \mathrm{M}$ phenylephrine. Whole cell extracts of $2 \times 10^{6}$ cardiomyocytes were assayed for caspase- 3 activity using a fluorogenic caspase-3 substrate. DEVD-AFC. The caspase-3 activity of cardiomyocytes at 0 time point was arbitrarily set as one. Activities were normalized to total protein and expressed as mean \pm S.E.M. $(n=4)$. ${ }^{*}$ The difference between samples with and without phenylephrine is statistically significant $(P<0.05)$. (B) Twenty micrograms of total protein from each cardiomyocyte sample were subjected to Western blot analysis. Protein blot was probed with an anti-PARP antibody, followed by chemiluminescence, $\mathrm{O}_{2} \mathrm{PM}$ : with both oxygen and serum: $\mathrm{O}_{2} \mathrm{MM}$ : with oxygen and without serum $(3 \mathrm{~h}) ; \mathrm{N}_{2} \mathrm{MM}$ : without oxygen and serum $(3 \mathrm{~h}) ; \mathrm{N}_{2} \mathrm{MM}+\mathrm{PE}$ : without oxygen and serum, with $50 \mu \mathrm{M}$ phenylephrine $(3 \mathrm{~h})$

signals. $^{15,26-30}$ To test whether phenylephrine-mediated protection involves regulation of mRNA expression of $\mathrm{Bcl}-2$ family members, we measured the steady state mRNA levels of $\mathrm{Bcl}-\mathrm{X}, \mathrm{Bcl}-2$, and $\mathrm{BAX}$ encoding genes by RNase protection assay. The mRNA levels of two house-keeping genes, GAPDH and L32, were measured as internal controls. As shown in Figure $5 \mathrm{~A}$, the steady state mRNA levels Bcl-2 and $\mathrm{Bcl}-\mathrm{X}$ were down-regulated in the cardiomyocytes treated with $24 \mathrm{~h}$ hypoxia and serum deprivation whereas the level of BAX mRNA was not significantly changed. The hypoxia and serum deprivation-induced down-regulation of both $\mathrm{Bcl}-2$ and $\mathrm{Bcl}-\mathrm{X}$ mRNAs was inhibited by co-treatment with $50 \mu \mathrm{M}$ phenylephrine. Quantification of the RNase protection results by the Storm System (Molecular Dynamics) indicated that the ratios of $\mathrm{Bcl}-\mathrm{X}: \mathrm{BAX}$ and $\mathrm{Bcl}-2 \mathrm{BAX}$ were significantly reduced
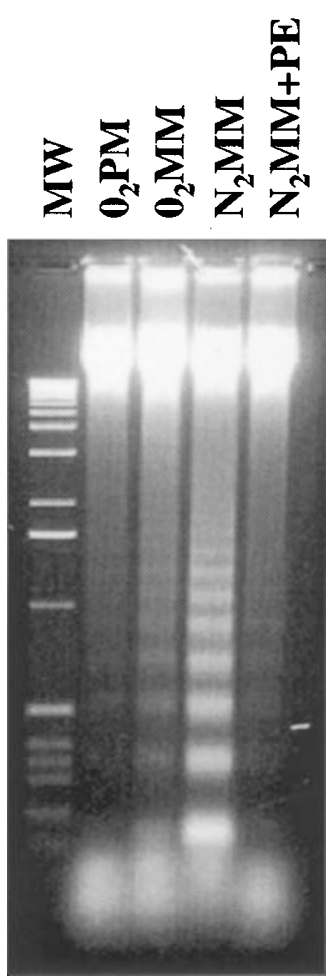

Figure 3 Phenylephrine inhibits hypoxia and serum deprivation-induced genomic DNA fragmentation. Five micrograms of genomic DNA isolated from cardiomyocytes under various conditions were analyzed by electrophoresis on a $1.5 \%$ agarose gel, followed by stained with ethidium bromide. MW: molecular weight standard ( $1 \mathrm{~kb}$ ladder, GIBCO $\mathrm{BRL}$ ); $\mathrm{O}_{2} \mathrm{PM}$ : with both oxygen and serum: $\mathrm{O}_{2} \mathrm{MM}$ : with oxygen and without serum (24h); $\mathrm{N}_{2} \mathrm{MM}$ : without oxygen and serum $(24 \mathrm{~h}) ; \mathrm{N}_{2} \mathrm{MM}+\mathrm{PE}$ : without oxygen and serum, with $50 \mu \mathrm{M}$ phenylephrine $(24 \mathrm{~h})$

(Figure 5B) by hypoxia and serum deprivation. However, the differences in these ratios between control cardiomyocytes and cardiomyocytes treated with hypoxia and serum deprivation in the presence of $50 \mu \mathrm{M}$ phenylephrine are not statistically significant. Similar pattern of regulation of these three genes by phenylephrine at the protein level was observed by Western blot analysis (Figure $5 \mathrm{C}$ ).

\section{Phenylephrine-mediated protection is abrogated by the PI 3-kinase inhibitor wortmannin and mimicked by the caspase-9 peptidic inhibitor LEHD-fmk}

$\alpha$-Adrenergic stimulation activates PI 3-kinase in both cardiac and smooth muscle cells. ${ }^{17,18}$ Active PI 3-kinase can protect cardiomyocyte against apoptosis by activating downstream Akt-1 kinase. ${ }^{19}$ To assess whether PI 3-kinase plays any roles in phenylephrine-mediated protection, the effects of the PI 3kinase inhibitor wortmannin were determined. Cardiomyocytes were treated with hypoxia and serum deprivation for $24 \mathrm{~h}$, either with $50 \mu \mathrm{M}$ phenylephrine or $50 \mu \mathrm{M}$ phenylephrine plus $20 \mu \mathrm{g} / \mathrm{ml}$ wortmannin and apoptosis was assessed by DNA fragmentation analysis. As shown in Figure 5D, phenylephrine-mediated protection was abrogated by cotreatment with $20 \mu \mathrm{g} / \mathrm{ml}$ wortmannin. Since one of the 

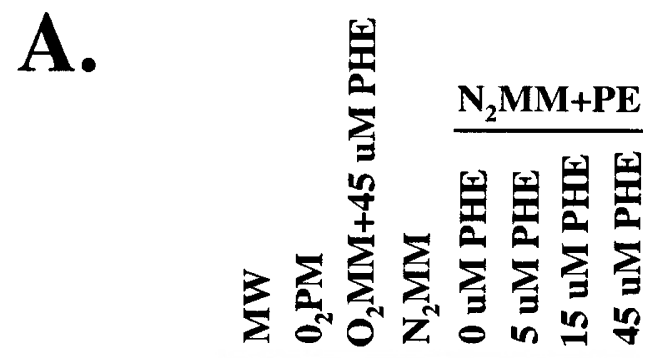

B.

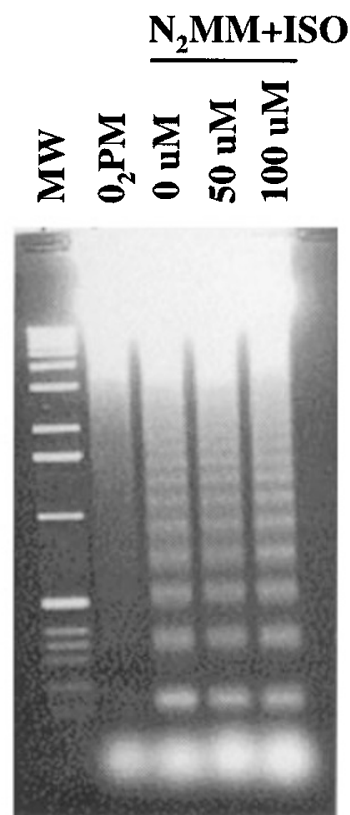

Figure 4 Phenylephrine inhibits hypoxia and serum deprivation-induced genomic DNA fragmentation through $\alpha$-adrenergic activation. (A, B) DNA fragmentation assay was performed as described in the legend of Figure 3. MW: molecular weight standard ( $1 \mathrm{~kb}$ ladder, GIBCO BRL); $\mathrm{O}_{2} \mathrm{PM}$, with both oxygen and serum $\mathrm{O}_{2} \mathrm{MM}+45 \mu \mathrm{M}$ PHE: with oxygen and without serum, with $45 \mu \mathrm{M}$ phentolamine (24h); $\mathrm{N}_{2} \mathrm{MM}$ : without oxygen and serum (24h); $\mathrm{N}_{2} \mathrm{MM}+\mathrm{PE}$ : without oxygen and serum, with $50 \mu \mathrm{M}$ phenylephrine (24h); $\mathrm{N}_{2} \mathrm{MM}+\mathrm{ISO}$ : without oxygen and serum, with indicated concentrations of isoproterenol $(24 \mathrm{~h})$

downstream targets of $\mathrm{PI}$ 3-kinase is Akt-1 kinase which prevents apoptosis by inhibiting activation of caspase- $9,{ }^{20}$ it was further determined whether inhibition of caspase- 9 would protect cardiomyocytes in the absence of phenylephrine. Genomic DNA fragmentation in cardiomyocytes, induced by $24 \mathrm{~h}$ treatment with hypoxia and serum deprivation, was inhibited by $40 \mu \mathrm{M}$ caspase- 9 peptidic inhibitor LEHD-fmk (Figure 5E).

\section{Phenylephrine induces expression of ANF mRNA and enlargement of neonatal cardiomyocytes under hypoxic conditions}

Since hypertrophic growth antagonizes apoptosis in cardiomyocytes and hepatocytes, ${ }^{31,32}$ we investigated whether phenylephrine induces hypertrophic growth in cardiomyocytes under hypoxic conditions by examining the expression of ANF mRNA. The steady state level of ANF mRNA in cardiomyocytes treated with $24 \mathrm{~h}$ hypoxia and serum deprivation in the presence or absence of $50 \mu \mathrm{M}$ phenylephrine was assessed by Northern blot analysis. As a control, RNA samples from $24 \mathrm{~h}$ phenylephrine-treated and nontreated cardiomyocytes cultured under normoxic conditions were included for the Northern blot analysis. The level of GAPDH mRNA was utilized as an internal control. As previously reported, the expression of ANF mRNA, one of the molecular markers for hypertrophy, was induced by phenylephrine under normoxic conditions (Figure 6A). Under hypoxic conditions, the expression of ANF mRNA was also induced by phenylephrine, suggesting that phenylephrine induces hypertrophic growth under hypoxic conditions.

This notion was supported by further morphological examination of cardiomyocytes. As shown in Figure 1, cardiomyocytes treated with phenylephrine displayed more organized sarcomeres than the non-treated cardiomyocytes under hypoxic conditions. Furthermore, it was assessed whether an enlargement in cardiomyocyte size under hypoxic conditions was induced by phenylephrine. Cardiomyocyte sizes were approximated by measuring the areas of cardiomyocytes stained with an anti- $\alpha$-actinin antibody, using the SigmaScan Pro software (Jandel Scientific Software). For each sample, the areas of 200 cardiomyocytes were measured. As shown in Figure 6B, under hypoxic conditions, phenylephrine-treated cardiomyocytes were significantly larger than non-treated cardiomyocytes (2.4 \pm 0.4 -fold, $P<0.05, n=5)$. A similar fold induction in cardiomyocyte size by phenylephrine under normoxic conditions was observed (2.6 \pm 0.6 -fold, $P<0.05, n=5)$. There is no significant difference in the size of phenylephrine-treated cardiomyocytes under either hypoxic or normoxic conditions. Data from both DNA fragmentation assay (Figure 6C) and morphological examination (data not shown) indicates that pre-treatment with $50 \mu \mathrm{M}$ phenylephrine under normoxic conditions for $24 \mathrm{~h}$ protects cardiomyocytes against subsequent $24 \mathrm{~h}$ insult of hypoxia and serum deprivation. Exposure of cardiomyocytes to $50 \mu \mathrm{M}$ phenylephrine for up to 9 days (with medium change every day) does not result in apoptosis (Figure 6D). However, genomic 


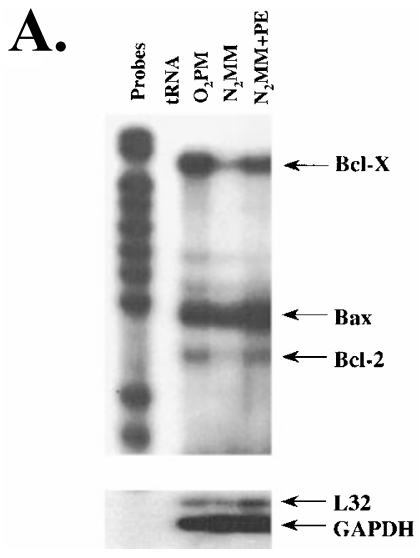

B.
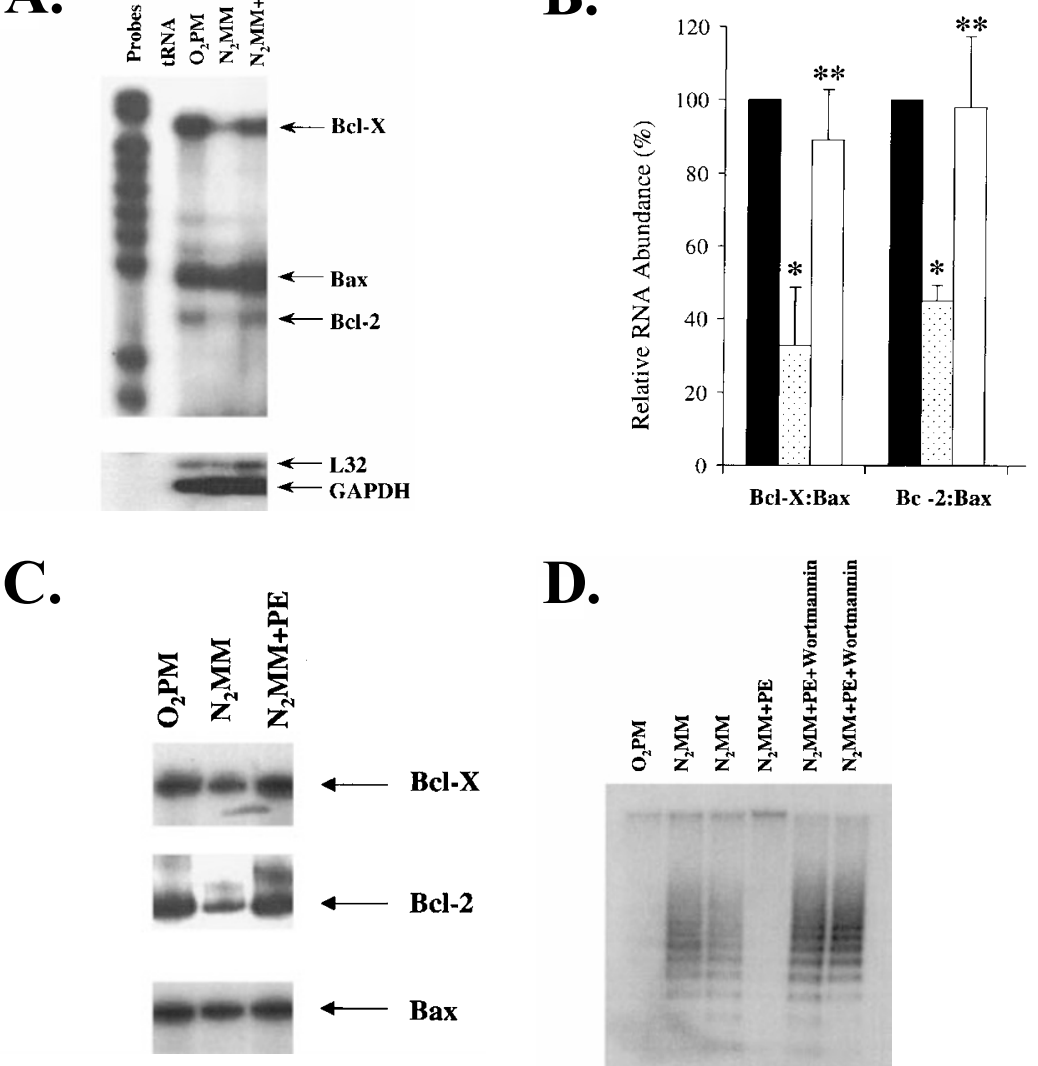

D.

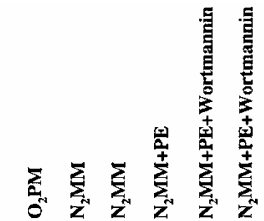

E.

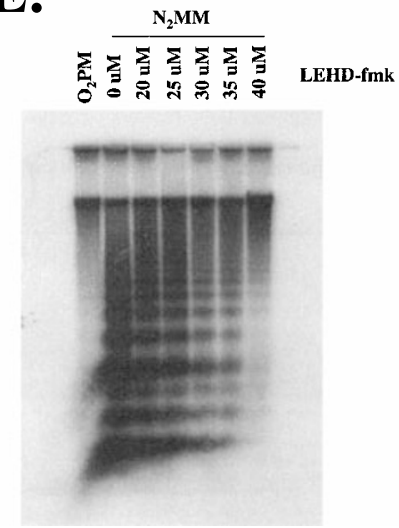

Figure 5 Phenylephrine inhibits hypoxia and serum deprivation-induced down-regulation of Bcl-X and Bcl-2 mRNAs. The mRNA levels of Bcl-X, Bcl-2, and BAX genes were determined by RNase protection assay using the RiboQuant system (PharMingen). The mRNA levels of L32 and GAPDH genes were used as internal controls. Ten micrograms of total RNA from each cardiomyocyte sample were subjected to RNase protection assay using a mixture of multiple probes (Fas, FasL, $\mathrm{Bcl}-\mathrm{X}, \mathrm{Bcl}-2$, BAX, caspase-1, caspase-2, caspase-8, L32, and GAPDH, only Bcl-X, Bcl-2, BAX, L32, and GAPDH mRNAs were repeatablly detectable). tRNA: $10 \mu \mathrm{g}$ yeast tRNA supplied in the kit (negative control); $\mathrm{O}_{2} \mathrm{PM}$ : with both oxygen and serum; $\mathrm{N}_{2} \mathrm{MM}$ : without oxygen and serum $(24 \mathrm{~h}) ; \mathrm{N}_{2} \mathrm{MM}+\mathrm{PE}$ : without oxygen and serum, with $50 \mu \mathrm{M}$ phenylephrine $(24 \mathrm{~h})$. (B) Quantification of the results of RNase protection assay by Storm System (Molecular Dynemics). The ratios of Bcl$\mathrm{X}: \mathrm{BAX}$ and $\mathrm{Bcl}-2 \mathrm{BAX}$ under $\mathrm{O}_{2} \mathrm{PM}$ conditions were arbitrarily set as $100 \%$ (solid bars) and the rest of data was expressed as mean $+\mathrm{S}$.E.M. ( $n=4$ ). Dotted bars: ratios of $\mathrm{Bcl}-\mathrm{X}: \mathrm{Bax}$ and $\mathrm{Bcl}-2: \mathrm{Bax}$ under $\mathrm{N}_{2} \mathrm{MM}$ conditions; open bars; ratios of $\mathrm{Bcl}-\mathrm{X}: \mathrm{Bax}$ and $\mathrm{Bcl}-2: \mathrm{Bax}$ under $\mathrm{N}_{2} \mathrm{MM}+\mathrm{PE}$ conditions: ${ }^{*}$ statistically significant $(P<0.05)$; ${ }^{*}$ statistically not significant. (C) Twenty micrograms of total protein from each cardiomyocyte sample were subjected to Western blot analysis. Protein blots were probed with an anti-Bcl-2, or Bcl- $\mathrm{X}_{\mathrm{S} / \mathrm{L}}$, or Bax antibody, followed by chemiluminescence. $\mathrm{O}_{2} \mathrm{PM}$ : with both oxygen and serum; $\mathrm{N}_{2} \mathrm{MM}$ : without oxygen and serum (24 h): $\mathrm{N}_{2} \mathrm{MM}+\mathrm{PE}$ : without oxygen and serum, with $50 \mu \mathrm{M}$ phenylephrine $(24 \mathrm{~h})$. (D) Cardiomyocytes were treated with hypoxia and serum deprivation for $24 \mathrm{~h}$ either with $50 \mu \mathrm{M}$ phenylephrine or $50 \mu \mathrm{M}$ phenylephrine plus $20 \mu \mathrm{g} / \mathrm{ml}$ wortmannin (Sigma). Half a microgram of genomic DNA from each sample was labeled by terminal deoxynucleotidyl transferase and $\left[\alpha_{-}{ }^{32} \mathrm{P}\right]-\mathrm{dATP}$, resolved on a $1.5 \%$ agarose gel, dried, and followed by autoradiography. $\mathrm{O}_{2} \mathrm{PM}$ : with both oxygen and serum: $\mathrm{N}_{2} \mathrm{MM}$ : without oxygen and serum; $\mathrm{N}_{2} \mathrm{MM}+\mathrm{PE}$ : without oxygen and serum, with $50 \mu \mathrm{M}$ phenylephrine; $\mathrm{N}_{2} \mathrm{MM}+\mathrm{PE}+$ Wortmannin: without oxygen and serum, with $50 \mu \mathrm{M}$ phenylephrine and $20 \mu \mathrm{g} / \mathrm{ml}$ wortmannin. (E) Cardiomyocytes were treated with hypoxia and serum deprivation for $20 \mathrm{~h}$ with various concentrations of LEHD-fmk. DNA fragmentation analysis was carried out as described in $\mathbf{D} . \mathrm{O}_{2} \mathrm{PM}$ : with both oxygen and serum; $\mathrm{N}_{2} \mathrm{MM}$ : without oxygen and serum 
A.

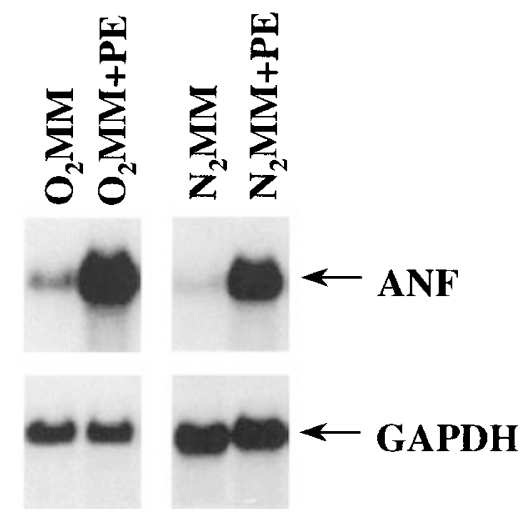

B.
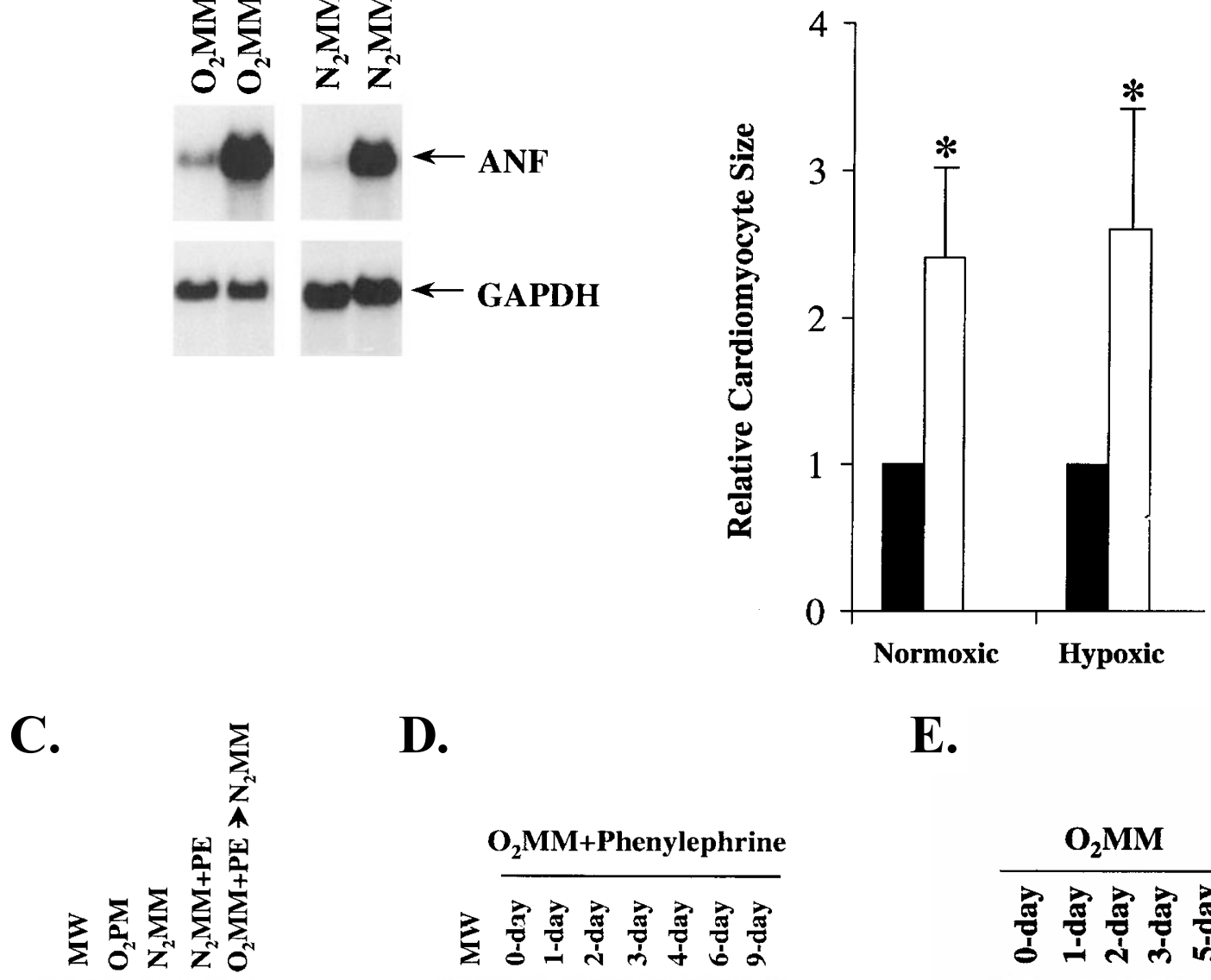

D.

E.

$\mathrm{O}_{2} \mathrm{MM}+$ Phenylephrine
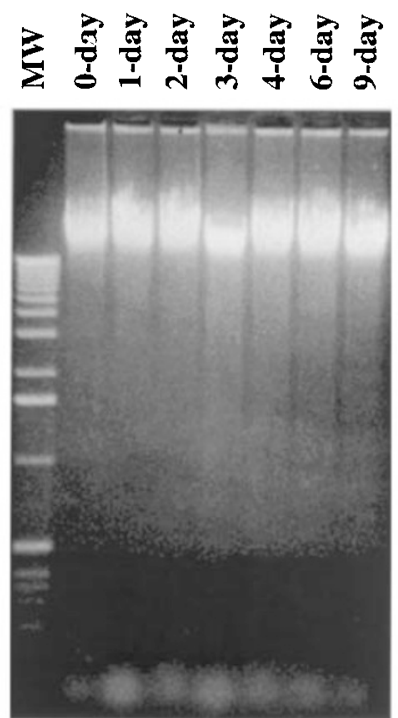
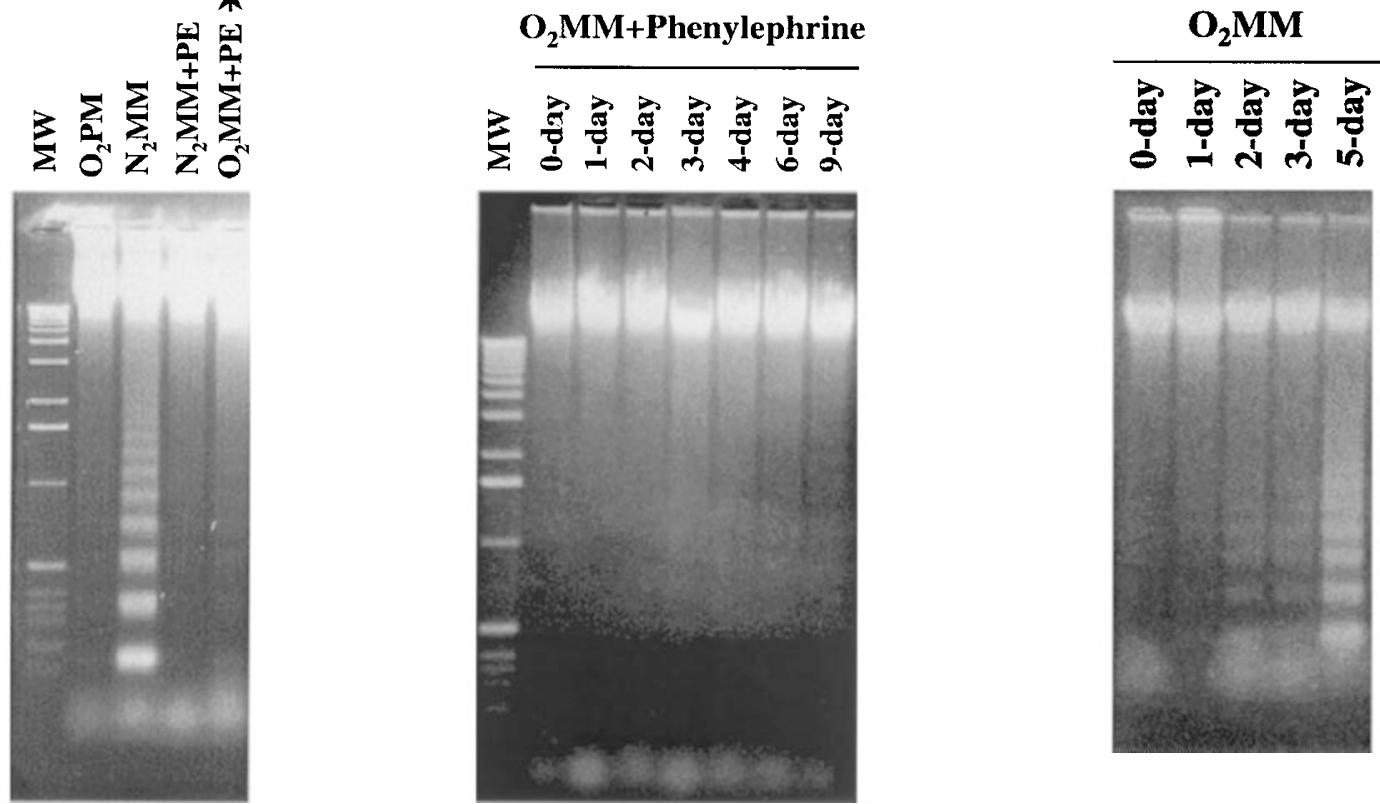

Figure 6 Phenylephrine activates hypertrophic program under hypoxic conditions. (A) Twenty micrograms of total RNA from each cardiomyocyte sample were subjected to Northern blot analysis. The RNA blot was probed with either an ANF cDNA fragment or a GAPDH cDNA fragment. $\mathrm{O}_{2} \mathrm{MM}$ : with oxygen without serum $(24 \mathrm{~h}) ; \mathrm{O}_{2} \mathrm{MM}+\mathrm{PE}$ : with oxygen without serum, with $50 \mu \mathrm{M}$ phenylephrine $(24 \mathrm{~h}) ; \mathrm{N}_{2} \mathrm{MM}$ : without oxygen and serum (24h); $\mathrm{N}_{2} \mathrm{MM}+\mathrm{PE}$ : without oxygen and serum, with $50 \mu \mathrm{M}$ phenylephrine $(24 \mathrm{~h}$ ). (B) Cardiomyocytes were treated with $0 \mu \mathrm{M}$ (solid bars) or $50 \mu \mathrm{M}$ (open bars) phenylephrine for $24 \mathrm{~h}$, under either normoxic or hypoxic conditions. Images of cardiomyocytes stained with the anti- $\alpha$-actinin antibody were utilized for area measurement. The areas of cardiomyocytes treated with $0 \mathrm{M}$ phenylephrine were arbitrarily set as one and the rest of data was expressed as mean \pm S.E.M. $(n=3,200$ cardiomyocytes were measured for each sample in each experiment). *Statistically significant $(P<0.05)$. (C, D) DNA fragmentation assay was performed as described in the legend of Figure 3. MW: molecular weight standard ( $1 \mathrm{~kb}$ ladder, GIBCO BRL); $\mathrm{O}_{2} \mathrm{PM}$, with both oxygen and serum; $\mathrm{N}_{2} \mathrm{MM}$ : without oxygen and serum ( $24 \mathrm{~h}$ ); $\mathrm{N}_{2} \mathrm{MM}+\mathrm{PE}$ : without oxygen and serum, with $50 \mu \mathrm{M}$ phenylephrine $(24 \mathrm{~h}) ; \mathrm{O}_{2} \mathrm{MM}+\mathrm{PE} \rightarrow \mathrm{N}_{2} \mathrm{MM}$ : cardiomyocytes were treated with $50 \mu \mathrm{M}$ phenylephrine under normoxia for $24 \mathrm{~h}$, washed twice with serumfree medium, and treated with hypoxia and serum-deprivation for $24 \mathrm{~h} . \mathrm{O}_{2} \mathrm{MM}+$ Phenylephrine: cardiomyocytes were treated with $50 \mu \mathrm{M}$ phenylephrine for indicated length of time (with medium change everyday). (E) Cardiomyocytes were treated with serum deprivation under normoxic conditions for $0,1,3$, and 5 days and DNA fragmentation was performed as described in $\mathbf{C}$ and $\mathbf{D}$. $\mathrm{O}_{2} \mathrm{MM}$ : with oxygen, without serum 
DNA fragmentation was observed on the second day of culture without phenylephrine and serum (Figure 6E), which is consistent with the pervious observation. ${ }^{23}$ On the fifth day of culture without phenylephrine and serum, majority of cardiomyocytes were detached from the culture dishes (data not shown) and a stronger DNA fragmentation signal was observed (Figure 6E).

\section{Discussion}

\section{Phenylephrine protects cultured cardiomyocytes against hypoxia and serum deprivation-induced apoptosis through $\alpha$ - but not $\beta$-adrenergic stimulation}

The current data shows that phenylephrine protects cultured neonatal cardiomyocytes against hypoxia and serum deprivation-induced apoptosis through $\alpha$-adrenergic stimulation. This in vitro observation, at least in part, explains the previous in vivo observation that $\alpha$-adrenergic activation is involved in ischemia/reperfusion preconditioning-mediated myocardial protection against subsequent sustained ischemia/reperfusion. Since majority of cardiomyocytes become postmitotic shortly after birth, cardiomyocyte apoptosis, induced by sustained ischemia/reperfusion, could lead to loss of cardiac muscle mass and thereby deterioration of cardiac functions. Therefore, one potential mechanism by which $\alpha$-adrenergic activation protects the myocardium from sustained ischemia/ reperfusion could be through inhibition of ischemia/reperfusion-induced cardiomyocyte apoptosis. A data from in vivo studies by Baghelai et a/ $f^{15}$ suggests that $\alpha$-adrenergic activation results in reduced apoptosis rate in the myocardium treated with sustained ischemia/reperfusion. Our current data shows directly the protection of isolated cardiomyocytes by $\alpha$-adrenergic activation against hypoxia and serum deprivation-induced apoptosis. In addition, $\alpha$-adrenergic activation may have a more general protective effect on cardiomyocytes both in vivo and in vitro. For instance, Wang and Ashraf have reported that $\alpha$-adrenergic activation during $\mathrm{Ca}^{2+}$ pre-conditioning protects the myocardium against subsequent $\mathrm{Ca}^{2+}$ overload injury. ${ }^{33}$ Iwai-Kanai et $a l^{16}$ have shown that CAMP-induced apoptosis in cultured neonatal rat cardiomyocytes can be blocked by $\alpha$-adrenergic activation.

\section{Integrity of mitochondria and apoptosis in cardiomyocytes}

In this study, we have shown that the ratios of Bcl-2:BAX and $\mathrm{Bcl}-\mathrm{X}$ :BAX mRNAs/proteins are down-regulated along with the occurrence of apoptosis in neonatal cardiomyocytes by $24 \mathrm{~h}$ treatment with hypoxia and serum deprivation. This down-regulation, however, is effectively abrogated by the cotreatment with $50 \mu \mathrm{M}$ phenylephrine. These results suggest that hypoxia and serum deprivation induces apoptosis in cardiomyocytes through, at least in part, by regulation of mitochondrion-associated apoptotic regulatory genes. It has been shown previously that down-regulation of $\mathrm{Bcl}-2$ and $\mathrm{Bcl}-$ $X$ results in leakage of mitochondrial proteins, in particular, cytochrome $\mathrm{c}$ into cytoplasm, which in turn activates caspase9 with Apaf- 1 and dATP. ${ }^{21}$ Activated caspase- 9 triggers an entire cascade of downstream caspase activation, including the major executioner, caspase-3. Our current data has shown that the endogenous caspase- 3 is activated by hypoxia and serum deprivation. Thus, the mitochondrion/ caspase-9 pathway could play a critical role in mediating ischemia-induced apoptosis in cardiomyocytes. As a piece of supportive evidence, our data shows that phenylephrinemediated protection is abrogated by the PI 3-kinase inhibitor wortmannin. PI 3-kinase is activated by $\alpha$-adrenergic stimulation $^{17,18}$ and protects cardiomyocytes by activating Akt-1 kinase. ${ }^{19}$ Akt-1 inhibits apoptosis, at least partially, by blocking activation of caspase- $9 .^{20}$ Our data demonstrates that phenylephrine-mediated inhibition of DNA fragmentation can be mimicked by the caspase- 9 peptidic inhibitor LEHDfmk. Therefore, phenylephrine may protect cardiomyocyte by the combination of maintaining the integrity of mitochondria and activating PI 3-kinase, which all lead to prevention of caspase- 9 activation.

Also consistent with our observation, not only have the decreases in the ratios of $\mathrm{Bcl}-2$ :BAX and $\mathrm{Bcl}-\mathrm{X}$ :BAX been observed in apoptotic cardiomyocytes in vivo and in vitro, ${ }^{15,26-30}$ but also the overexpression of either $\mathrm{Bcl}-2$ or $\mathrm{Bcl}-\mathrm{X}$ protein can protect cardiomyocytes against apoptosis. $^{34-36}$ In addition, Baghelai et $a l^{15}$ have also shown that $\alpha$-adrenergic activation-mediated myocardial protection from sustained ischemia/reperfusion is correlated with an increase in the $\mathrm{Bcl}-\mathrm{X}: \mathrm{BAX}$ protein ratio in the myocardium. Besides $\mathrm{Bcl}-2$ and $\mathrm{Bcl}-\mathrm{X}$, phenylephrine may also up- or down-regulate other apoptosis regulatory genes in cardiomyocytes in response to various insults. Therefore, our current in vitro model system provides an opportunity to identify cardiac apoptosis regulatory genes, which could potentially serve as pharmaceutical targets for intervening cardiac apoptosis.

\section{Possible antagonistic relationship between hypertrophy and apoptosis in cultured cardiomyocytes}

It has been reported that cardiomyocyte apoptosis is elevated in decompensatory hypertrophy, suggesting that hypertrophy could lead to apoptosis. ${ }^{37-40}$ However, our current data shows that a well-characterized hypertrophy stimulus, phenylephrine, not only does not induce apoptosis in cultured neonatal cardiomyocytes under in vitro normoxic conditions, but it protects these cardiomyocytes against hypoxia and serum deprivation-induced apoptosis. In addition, cardiomyocytes pre-treated with phenylephrine for $24 \mathrm{~h}$ are protected from subsequent $24 \mathrm{~h}$ treatment with hypoxia and serum deprivation. This apparent discrepancy could be explained by at least two possibilities. First, sustained hypertrophy in vivo could become decompensatory, which results in a number of detrimental changes in the ventricular muscle. For instance, regional ischemia can be evoked by the combination of thickening of ventricular wall and lack of appropriate angiogenesis during decompensatory hypertrophy, ${ }^{41,42}$ which can induce cardiomyocyte apoptosis. ${ }^{1-5,43-46}$ In addition, decompensatory hypertrophy can also be accompanied by infiltration of macrophages and neutrophils in the ventricular muscle which secrete pro-apoptosis cytokines 
such as IL-1 $\beta$, TNF $\alpha$, NO, and angiotensin II. ${ }^{30,47,48}$ Therefore, cardiomyocyte apoptosis could be a direct result of these decompensatory hypertrophy-triggered detrimental changes, instead of hypertrophic growth itself. Consistent with this notion, elevation in cardiomyocyte apoptosis during compensatory hypertrophy, which is not accompanied by the above detrimental changes, has not been observed. There is probably not always a cause-and-effect relationship between the onset of hypertrophic program and the onset of apoptotic program in cardiomyocytes. This notion is supported by an observation that hypertrophy in neonatal cardiomyocytes is mediated by the $\beta$-isoform of p38 mitogen-activated protein kinase whereas apoptosis is mediated by the $\alpha$-isoform. ${ }^{49}$ On the other hand, cardiomyocytes, induced to develop hypertrophy in vitro, do not encounter those detrimental changes occurring during decompensatory hypertrophy in vivo since there is always sufficient oxygen and serum in the culture medium. Furthermore, cardiomyocytes begin hypertrophic program with a transient activation of several protooncogenes, such as c-jun, c-fos, c-myc, erg-1, and nur77, and subsequent activation of the ras/ERK signaling pathway. ${ }^{50-52}$ Hence, it is not difficult to envision that activation of hypertrophy could potentially antagonize apoptosis in cardiomyocytes. Tone et $a^{F^{3}}$ has shown that LIF can protect cardiomyocytes against apoptosis by activating the JAKSTAT signaling pathway, which is also involved in hypertrophic growth. Double allelic null mutations of the gp130 gene, which encodes a component of LIF receptor, lead to massive myocyte apoptosis in response to pressure overload. $^{54}$ It has been shown in both cardiomyocytes and hepatocytes, activation of hypertrophic growth antagonizes apoptosis. ${ }^{31,32}$ These observations suggest an antagonistic relationship between hypertrophic growth and apoptotic cell death. Despite the above examples, the antagonistic effects of hypertrophy on apoptosis may not be a universal rule since the $\mathrm{Gq}$ pathway can lead to hypertrophy and apoptosis depending upon the level of activation. ${ }^{55}$

The second possibility is that in addition to activating hypertrophy, phenylephrine also regulates expression of apoptosis regulatory genes in cardiomyocytes, which are independent of hypertrophic growth. Our current results have shown that the expression of two mitochondrionassociated anti-apoptotic genes. $\mathrm{Bcl}-2$ and $\mathrm{Bcl}-\mathrm{X}$, in cultured neonatal cardiomyocytes is regulated by phenylephrine under hypoxic conditions. This regulation could account for a part of phenylephrine-mediated cytoprotection. Although it is difficult to distinguish these two possibilities at present, it is likely that both possibilities contribute to the phenylephrine-mediated protection. More experiments are needed to assess the relative importance of these two possible mechanisms.

In conclusion, our current studies indicate that apoptosis is not an obligatory consequence of hypertrophy in isolated neonatal cardiomyocytes. To our best knowledge, our data, for the first time, demonstrates that hypoxia and serum deprivation-induced cardiomyocyte apoptosis in vitro can be effectively inhibited by a hypertrophy-inducing stimulus, phenylephrine. Although $\alpha$-adrenergic receptor agonists may not be ideal pharmaceutical targets for intervening in apoptosis due to reasons such as vasoconstriction. It can be conceptually envisioned that phenylephrine-regulated genes may potentially serve as pharmaceutical targets.

\section{Materials and Methods}

\section{Isolation and culturing of neonatal rat cardiomyocytes}

The investigation conforms with the Guide for the Care and Use of Laboratory Animals published by the US National Institute of Health (NIH Publication No. 85-23, revised 1996). The isolation and culture of neonatal rat ventricular myocytes are described previously. ${ }^{56}$ Sprague-Dawley is the only rat strain utilized for all the experiments performed in the current studies. Ventricular myocytes were dispersed from the ventricles of 1-day-old neonatal rats by digestion with collagenase II (Worthington) and pancreatin (GIBCO BRL) at $37^{\circ} \mathrm{C}$. Myocytes were further purified by a discontinuous Percoil (Pharmacia Biotechnology Inc) gradient to obtain myocardial culture with $>95 \%$ myocytes, as assessed by immunofluorescence staining with an antibody (EA53. Sigma) against muscle specific $\alpha$-actinin. Myocytes were plated on collagen type I-coated $10-\mathrm{cm}$ dish $\left(5 \times 10^{6}\right.$ cells per dish) or 2-well chamber slides $\left(0.5 \times 10^{6}\right.$ cells per well) (BIOCOAT Becton Dickinson) in DMEM+199 (4:1)+5\% FBS+10\% horse serum for $36 \mathrm{~h}$ with one change of medium. To induce apoptosis, myocytes were switched to serum-free medium and placed in a hypoxic chamber (Forma Scientific) with $95 \% \mathrm{~N}_{2}+5 \% \mathrm{CO}_{2}$ for $24 \mathrm{~h}$. The caspase-9 peptidic inhibitor, LEHD-fmk. ${ }^{57}$ was purchased from Enzyme System Products.

\section{Assessment of cardiomyocytes apoptosis}

The morphology of myocytes was examined by phase contrast and fluorescent microscopy following immunofluorescent staining with an anti- $\alpha$-actinin antibody and Hoechst33258. Myocytes in one well of 2well chamber slides were rinsed with PBS and fixed for $15 \min 25^{\circ} \mathrm{C}$ in $2 \mathrm{ml}$ of $3 \%$ paraformaldehyde in buffer $\mathrm{A}$ ( $10 \mathrm{mM}$ sodium phosphate, $\mathrm{pH} 7.4,150 \mathrm{mM} \mathrm{NaCl}$, and $1 \mathrm{mM} \mathrm{MgCl}_{2}$ ). The cells were changed into $2 \mathrm{ml}$ of $50 \mathrm{mM} \mathrm{NH}_{4} \mathrm{Cl}$ in buffer $\mathrm{A}$ and incubated at $25^{\circ} \mathrm{C}$ for $10 \mathrm{~min}$. After they were washed twice with PBS, the cells were permeabilized with $2 \mathrm{ml}$ of $0.2 \%$ Triton $\mathrm{X}-100$ in buffer $\mathrm{A}$ at $25^{\circ} \mathrm{C}$ for $15 \mathrm{~min}$, followed by three additional washes with PBS. The slides were blocked with $1 \%$ bovine serum albumin for $10 \mathrm{~min}$ at $25^{\circ} \mathrm{C}$, incubated with an antibodies against muscle specific $\alpha$-actinin (diluted 20 -fold) for $60 \mathrm{~min}$ at $37^{\circ} \mathrm{C}$, rinsed, and washed four times with PBS. The cells in chamber slides were then incubated with a goat anti-mouse IgG antibody-conjugated with a CY2 fluorescent dye at $37^{\circ} \mathrm{C}$ for $60 \mathrm{~min}$. After being rinsed once and washed four times with PBS, they were stained with Hoechst33258 $(0.1 \mathrm{mg} / \mathrm{ml}$ in PBS $)$ at $25^{\circ} \mathrm{C}$ for $10 \mathrm{~min}$. Following two washes with PBS, the slides were mounted on glass coverslips with Anti-Fade and viewed by fluorescence microscopy. Images of phase, fluorescent staining with the anti- $\alpha$-actinin antibody and Hoechst 33258 from the same fields were recorded from a Nikon TE300 microscope by a Image-Pro Plus v4.0 program (Media Cybernetics). The areas of myocytes were measured by SigmaScan 3.0 software (Jandel Scientific Software) using the images of myocytes stained with the anti- $\alpha$-actinin antibody and used as the approximation of the cell size. For each sample, the areas of 200 myocytes were measured by this method.

An ApoAlert Caspase-3 Fluorescent Assay Kit (Clontech) was utilized to measure the activity of endogenous caspase- 3 activity. Myocytes cultured in a $10-\mathrm{cm}$ dish were washed twice with ice-cold PBS and harvested by scrapping and centrifugation in a microfuge 
(4000 r.p.m. for $10 \mathrm{~min}$ at $4^{\circ} \mathrm{C}$ ). Myocytes were then lysed in $100 \mu \mathrm{l}$ Lysis Buffer for $10 \mathrm{~min}$ on ice and cell debris was removed by centrifugation in a microfuge (15 000 r.p.m. for 3 min at $4^{\circ} \mathrm{C}$ ). Caspase- 3 reaction was carried out by incubating the mixture of $50 \mu \mathrm{l}$ cell lysate. $50 \mu \mathrm{l} 2 \times$ Reaction Buffer, and $5 \mu \mathrm{l}$ substrate (DEVDAFC, $50 \mu \mathrm{M}$ final) at $37^{\circ} \mathrm{C}$ for $2 \mathrm{~h}$. The activity of caspase- 3 was quantified by measuring the fluorescence $(400-\mathrm{nm}$ excitation, $505-\mathrm{nm}$ emission) of each reaction using a VersaFluor fluorometer (BioRad).

Western blot analysis was carried out, using an WesternBreeze kit (Novex), according to the vendor's protocol, to detect the endogenous PARP protein. Twenty micrograms of total protein from each sample were separated by SDS-PAGE, transferred to nitrocellulose membrane (BioRad), and probed with an anti-PARP (Stratagene), or Bcl-2 (Santa Cruz Biotechnology), or Bcl- $\mathrm{X}_{\mathrm{S} / \mathrm{L}}$ (Santa Cruz Biotechnology), or Bax (Santa Cruz Biotechnology) antibody. Antibody binding was detected by an goat anti-mouse or rabbit IgG antibody and chemiluminescence.

To detect DNA fragmentation by gel electrophoresis, genomic DNA was isolated from myocytes using a DNA Isolation Kit (Puregene) and resolved on a $1.5 \%$ agarose gel. Myocytes in one $10-\mathrm{cm}$ dish were rinsed with $10 \mathrm{ml}$ PBS at room temperature and lysed in $600 \mu \mathrm{l}$ Lysis Buffer. Lysate was transferred to a clean $1.5-\mathrm{ml}$ microfuge tube containing $3 \mu \mathrm{l} \mathrm{RNaseA}(20 \mu \mathrm{g} / \mathrm{ml})$ and incubated at $37^{\circ} \mathrm{C}$ for $1 \mathrm{~h}$. After being cooled to room temperature, the lysate was then mixed with $200 \mu \mathrm{l}$ of Protein Precipitation Solution and centrifuged in a microfuge at 15000 r.p.m. for $3 \mathrm{~min}$ at room temperature. The supernatant was transferred to a fresh $1.5-\mathrm{ml}$ microfuge tube and mixed with $600 \mu$ $100 \%$ isopropanol. DNA was pelleted by centrifugation in a microfuge at 15000 r.p.m. for $1 \mathrm{~min}$ at room temperature and washed with $1 \mathrm{~m}$ $70 \%$ ethanol. After air drying for $15 \mathrm{~min}$. DNA was re-hydrated in $50 \mu \mathrm{l}$ DNA Hydration Solution over night at $4^{\circ} \mathrm{C}$. Five micrograms of isolated genomic DNA were resolved on a $1.5 \%$ agarose gel and viewed by ethidium bromide staining. Alternatively, $0.5 \mu \mathrm{g}$ genomic DNA was labeled by incubating with 5 units of terminal deoxynucleotidyl transferase and $3 \mu \mathrm{l}\left[\alpha^{-}{ }^{32} \mathrm{P}\right]-\mathrm{dATP}(10 \mu \mathrm{i} / \mu \mathrm{l})$ in $30 \mu \mathrm{l} 1 \times$ Tailing Buffer (Stratagene) for $1 \mathrm{~h}$ at $37^{\circ} \mathrm{C}$. The unincorporated $\left[\alpha^{32} \mathrm{P}\right]$-dATP was removed by a Chrom-30 spin column (Sigma) according to manufacture's protocol. Labeled DNA was resolved on a $1.5 \%$ agarose gel, dried. and followed by autoradiography.

\section{Northern blot analysis}

Total RNA was isolated from myocytes using the TRIZOL Reagent (GIBCO BRL). After one wash with $10 \mathrm{ml}$ PBS at room temperature, myocytes in a 10-cm dish were lysed in $1 \mathrm{ml}$ TRIZOL Reagent and the lysate was mixed in a clean $1.5-\mathrm{ml}$ microfuge tube with $0.2 \mathrm{ml}$ chloroform and incubated at room temperature for $3 \mathrm{~min}$. After centrifugation in a microfuge at 15000 r.p.m. for $15 \mathrm{~min}$ at $4^{\circ} \mathrm{C}$, the RNA supernatant was mixed with $0.5 \mathrm{ml} 100 \%$ isopropanol in a fresh $1.5-\mathrm{ml}$ microfuge tube and the mixture was centrifuged in a microfuge at 15000 r.p.m. for $10 \mathrm{~min}$ at $4^{\circ} \mathrm{C}$ to pellet RNA. After one wash with $1 \mathrm{ml} \mathrm{75 \%}$ ethanol. RNA pellet was resuspended in $30 \mu \mathrm{l}$ RNase-free $\mathrm{H}_{2} \mathrm{O}$. Twenty micrograms of total RNA of each sample were resolved on a $1 \%$ formaldehyde agarose gel and transferred from the agarose gel to a nylon membrane by capillary blotting and fixed by UV crosslinking. Prehybridization was carried out in an ExpressHyb Solution (Clontech) for $30 \mathrm{~min}$ at $68^{\circ} \mathrm{C}$ and hybridization was carried out in fresh ExpressHyb Solution containing radiolabeled cDNA probe for $1 \mathrm{~h}$ at $68^{\circ} \mathrm{C}$. The RNA blot was washed three times in Wash Solution I $(2 \times$ SSC $+0.05 \%$ SDS $)$ for $10 \mathrm{~min}$ each at room temperature, twice in Wash Solution II $(0.1 \times \mathrm{SSC}+0.1 \% \mathrm{SDS})$ for $20 \mathrm{~min}$ each at $50^{\circ} \mathrm{C}$. The blot was then exposed to Kodak X-ray film.

\section{RNase protection assay}

RNase protection assay was performed to measure the steady state levels of mRNAs for several apoptosis regulatory genes using the RiboQuant kit (PharMingen). The mRNA levels of the ribosomal protein. L32, and GAPDH were used as the internal controls. Radioactive RNA probes were synthesized in a reaction containing $1 \mu \mathrm{l}$ RNasin $(40 \mathrm{u} / \mu \mathrm{l}), 1 \mu \mathrm{l} \mathrm{GACU}$ pool $(2.75 \mathrm{mM}$ of GTP, ATP, CTP, and $61 \mu \mathrm{M}$ UTP), $2 \mu \mathrm{l}$ DTT (100 mM), $4 \mu \mathrm{l} 5 \times$ Transcription Buffer, $1 \mu \mathrm{l}$ RPA Template Set. $10 \mu \mathrm{l}\left[\alpha_{-}{ }^{32} \mathrm{P}\right]$-UTP $(3000 \mathrm{Ci} / \mathrm{mmol})$ and $1 \mu \mathrm{l} \mathrm{T7}$ RNA polymerase $(20 \mathrm{u} / \mu \mathrm{l})$ for $1 \mathrm{~h}$ at $37^{\circ} \mathrm{C}$. The reaction was terminated by adding $2 \mu \mathrm{l}$ DNase and incubating for $30 \mathrm{~min}$ at $37^{\circ} \mathrm{C}$. Phenol-chloroform extraction was carried out after the followings are added to each reaction: $26 \mu \mathrm{l} 20 \mathrm{mM}$ EDTA. $25 \mu \mathrm{l}$ Tris-saturated phenol. $25 \mu$ l chloroform:isoamyl alcohol (50:1), and $2 \mu$ yeast tRNA $(2 \mathrm{mg} / \mathrm{ml})$. RNA probes were then precipitated with $50 \mu \mathrm{l} 4 \mathrm{M}$ ammonium acetate and $250 \mu 100 \%$ ethanol and resuspended in $50 \mu \mathrm{l}$ Hybridization Buffer. Ten micrograms of total RNA resuspended in $8 \mu \mathrm{l}$ Hybridization Buffer were mixed with $2 \mu \mathrm{l}$ radioactive RNA probes ( $\sim 5 \times 10^{4}$ Cherenkov counts) and heated at $90^{\circ} \mathrm{C}$ for $1 \mathrm{~min}$. The mixture was cooled down gradually to $56^{\circ} \mathrm{C}$ and incubated at $56^{\circ} \mathrm{C}$ for $16 \mathrm{~h}$. After being further cooled down gradually to $37^{\circ} \mathrm{C}$, RNase digestion was performed by adding $125 \mu \mathrm{l}$ RNase Buffer and $0.3 \mu \mathrm{l}$ RNase $\mathrm{A} / \mathrm{T} 1$ and incubating at $30^{\circ} \mathrm{C}$ for $45 \mathrm{~min}$. RNase digestion was terminated by Proteinase $\mathrm{K}$ digestion with $19 \mu \mathrm{l}$ Proteinase Buffer $+1.5 \mu \mathrm{l}$ Proteinase $\mathrm{K}(10 \mathrm{mg} / \mathrm{ml})+30 \mu \mathrm{l}$ tRNA $(2 \mathrm{mg} / \mathrm{ml})$ for $15 \mathrm{~min}$ at $37^{\circ} \mathrm{C}$. Phenol/chloroform extraction and ethanol precipitation were carried out as described above and the RNA pellet was resuspended in $5 \mu \mathrm{l}$ sequencing gel loading buffer. The reaction was resolved on a precasted $8 \%$ sequencing gel (Norvex) which was then dried in a microwave oven ( $3 \mathrm{~min}$ ) and exposed to Kodak X-ray film.

\section{Statistics}

Values of experimental data were expressed as mean \pm S.E.M. Statistical analysis was performed using the Mann-Whitney $U$-test. Results were considered significant if $P<0.05$.

\section{Acknowledgments}

The authors would like to thank Drs. Linda Merkel-Jordan and Ming Qi for productive discussions on this project.

\section{References}

1. Itoh G, Tamura J, Suzuki M, SuzukiY, Ikeda H, Koike M, Nomura M, Jie T and Ito K (1995) DNA fragmentation of human infarcted myocardial cells demonstrated by the nick end labeling method and DNA agarose gel electrophoresis. Am. J. Pathol. 146: 1325-1331

2. Fliss $H$ and Gattinger (1996) Apoptosis in ischemic and reperfused rat myocardium. Circ. Res. 79: 949-956

3. Bardales R, Hailey L, Xie S, Schaefer R and Hsu S (1996) In situapoptosis assay for the detection of early acute myocardial infarction. Am. J. Pathol. 149: $821-$ 829

4. Olivetti G, Quaini F, Sala R, Lagrasta C, Corradi D, Bonacina E, Gambert S, Cigola $E$ and Anversa P (1996) Acute myocardial infarction in humans is associated with activation of programmed myocyte cell death in the surviving portion of the heart. J. Mol. Cell. Cardiol. 28: 2005-2016

5. Kajstura J, Liu Y, Baldini A, Li B, Olivetti G, Leri A and Anversa P (1998) Coronary artery constriction in rats: necrotic and apoptotic myocyte death. Am. J. Cardiol. 82: $30 \mathrm{~K}-41 \mathrm{~K}$ 
6. Claycomb WC (1992) Control of cardiac muscle cell division. Trends Cardiovasc. Med. 2: 231-236

7. Schneider MD (1996) Myocardial infarction as a problem of growth control: cell cycle therapy for cardiac myocytes? Card. Fail. 2: 259-263

8. Zhu H (1997) Myocardial cellular development and morphogenesis. In The Myocardium, Langer GA, ed (San Diego, CA: Academic Press, 2nd edn.), pp. 33-71

9. Meldrum DR (1997) Mechanisms of cardiac preconditioning: ten years after the discovery of ischemic preconditioning. J. Surg. Res. 73: 1-13

10. Takeo $S$ and Nasa $Y$ (1999) Role of energy metabolism in the preconditioned heart - a possible contribution of mitochondria. Cardiovasc. Res. 43: 32-43

11. Perrault LP and Menasche P (1999) Preconditioning: can nature's shield be raised against surgical ischemic-reperfusion injury? Ann. Thorac. Surg. 68: 1988-1994

12. Banerjee A, Locke-Winter C, Rogers KB, Mitchell MB, Brew EC, Cairns CB Bensard DD and Harken AH (1993) Preconditioning against myocardial dysfunction after ischemia and reperfusion by an $\alpha 1$-adrenergic mechanism. Cir. Res. 73: 656-670

13. Cleveland Jr JC, Meldrum DR, Rowland RT, Cain BS, Meng XZ, GamboniRobertson $A B$ and Harken $A H$ (1997) Ischemic preconditioning of human myocardium: protein kinase $C$ mediates a permissive role for $\alpha$-adrenoceptors. Am. J. Physiol. 273: H902-H908

14. Cope JT, Mauney MC, Banks D, Binns OAR, Moore CL, Rentz JJ, Shockey KS King RC, Kron IL and Tribble CG (1997) Intravenous phenylephrine preconditioning of cardiac grafts from non-heart-beating donors. Ann. Thorac. Surg. 63: $1664-1668$

15. Baghelai K, Graham LJ, Wechsler AS and Jakoi AR (1999) Delayed myocardial preconditioning by $\alpha 1$-adrenoceptors involves inhibition of apoptosis. J. Thorac. Cardiovasc. Surg. 117: $980-986$

16. Iwai-Kanai E, Hasegawa K, Araki M, Kakita T, Morimoto T and Sasayama S (1999) $\alpha$ - and $\beta$-adrenergic pathways differentially regulate cell type-specific apoptosis in rat cardiac myocytes. Circulation 100: 305-311

17. Schluter KD, Simm A, Schafer M, Taimor G and Piper HM (1999) Early response kinase and PI 3-kinase activation in adult cardiomyocytes and their role in hypertrophy. Am. J. Physiol. 276 (5 Pt 2): H1655-H1663

18. Hu ZW, Shi XY, Lin RZ and Hoffman BB (1996) Alpha 1 adrenergic receptors activate phosphatidylinositol 3-kinase in human vascular smooth muscle cells. Role in mitogenesis. J. Biol. Chem. 271: 8977-8982

19. Fujio Y, Nguyen T, Wencker D, Kitsis RN and Walsh K (2000) Akt promotes survival of cardiomyocytes in vitro and protects against ischemia-reperfusion injury in mouse heart. Circulation 101: 660-667

20. Cardone MH, Roy N, Stennicke HR, Salvesen GS, Franke TF, Stanbridge E, Frisch S and Reed JC (1998) Regulation of cell death protease caspase-9 by phosphorylation. Science 282: 1318-1321

21. Li P, Nijhawan D, Budihardjo I, Srinivasula SM, Ahmad M, Alnemri ES and Wang X (1997) Cytochrome $c$ and dATP-dependent formation of Apaf-1/caspase-9 complex initiates an apoptotic protease cascade. Cell 91: 479-489

22. Tanaka M, Ito H, Adachi S, Akimoto H, Nishikawa T, Kasajima T, Marumo F and Hiroe M (1994) Hypoxia induces apoptosis with enhanced expression of Fas antigen messenger RNA in cultured neonatal rat cardiomyocytes. Circ. Res. 75 $426-433$

23. Sheng Z, Knowlton K, Chen J, Hoshijima M, Brown JH and Chien KR (1997) Cardiotrophin $\mathrm{nl}(\mathrm{CT}-1)$ inhibition of cardiac myocyte apoptosis via a mitogenactivated protein kinase-dependent pathway. J. Biol. Chem. 272: 5783-5791

24. Long X, Boluyt M, Hipolito M, Lundberg M, Zheng J, O'Neill L, Cirielli C, Lakatta E and Crow M (1997) p53 and the hypoxia-induced apoptosis of cultured neonatal rat cardiac myocytes. J. Clin. Invest. 99: 2635-2643

25. Chen SJ, Bradley ME and Lee TC (1998) Chemical hypoxia triggers apoptosis of cultured neonatal rat cardiac myocytes: modulation by calcium-regulated proteases and protein kinases. Mol. Cell. Biochem. 178: 141-149

26. Leri A, Claudio P, Li Q, Wang X, Reiss K, Wang S, Malhotra A, Kajstura J and Anversa $P$ (1998) Stretch-mediated release of angiotensin II induces myocyte apoptosis by activating $\mathrm{p} 53$ that enhances the local renin-angiotensin system and decreases the Bcl-2-to-BAX protein ratio in the cell. J. Clin. Invest. 101: $1326-1342$

27. Wang L, Ma W, Markovich R, Chen J and Wang P (1998) Regulation of cardiomyocyte apoptotic signaling by insulin-like growth factor I. Circ. Res. 83: $516-522$

28. MaulikN, Goswami S, Galang Nand Das D (1999) Differential regulation of Bcl-2. AP-1 and NF-kappaB on cardiomyocyte apoptosis during myocardial ischemic stress adaptation. FEBS Lett. 443: $331-336$
29. Misao J, Hayakawa Y, Ohno M, Kato S, Fujiwara T and Fujiwara H (1996) Expression of bcl-2 protein, an inhibitor of apoptosis, and BAX, an accelerator of apoptosis, in ventricular myocytes of human hearts with myocardial infarction. Circulation 94: 1506-1512

30. Ing D, Zang J, Dzau V, Webster Kand Bishopric N (1999) Modulation of cytokineinduced cardiac myocyte apoptosis by nitric oxide, Bak, and Bcl-x. Circ. Res. 84: 21-33

31. Sanders Sand Thorgeirsson SS (1999) Phenobarbital promotes livergrowth in cmyc/TGF-alpha transgenic mice by inducing hypertrophy and inhibiting apoptosis. Carcinogenesis 20: $41-49$

32. De Windt LJ, Lim HW, Taigen T, Wencker D, Condorelli G, Dorn II GW, Kitsis RN and Molkentin JD (2000) Calcineurin-mediated hypertrophy protects cardiomyocytes from apoptosis in vitro and in vivo: An apoptosis-independent model of dilated heart failure. Circ. Res. 86: 255-263

33. Wang $Y$ and Ashraf $M$ (1998) Activation of $\alpha 1$-adrenergic receptor during $\mathrm{Ca}^{2+}$ preconditioning elicits strong protection against $\mathrm{Ca}^{2+}$ overload injury via protein kinase C signaling pathway. J. Mol. Cell. Cardiol. 30: 2423-2435

34. Kirshenbaum $L$ and de Moissac D (1997) The bcl-2 gene product prevents programmed cell death of ventricular myocytes. Circulation 96: 1580-1585

35. de Moissac D, Mustapha S, Greenberg A and Kirshenbaum L (1998) Bcl-2 activates the transcription factor NFkappaB through the degradation of the cytoplasmic inhibitor IkappaBalpha. J. Biol. Chem. 273: 23946-23951

36. Kirshenbaum L (1998) Regulators of apoptosis in the heart: a matter of life and death. Can. J. Cardiol. 14: 457-460

37. Diez J, Panizo A, Hernandez M, Vega F, Sola I, Fortuno M and Pardo J (1997) Cardiomyocyte apoptosis and cardiac angiotensin-converting enzyme in spontaneously hypertensive rats. Hypertension 30: 1029-1034

38. Ino T, Nishimoto K, Okubo M, Akimoto K, Yabuta K, Kawai S, Okada R and Sueyoshi N (1997) Apoptosis as a possible cause of wall thinning in end-stage hypertrophic cardiomyopathy. Am. J. Cardiol. 79: 1137-1141

39. Sabbah H and Sharov V (1998) Apoptosis in heart failure. Prog. Cardiovasc. Dis. 40: $549-562$

40. Diez J, Fortuno M and Ravassa S (1998) Apoptosis in hypertensive heart disease. Curr. Opin. Cardiol. 13: 317-325

41. Tomanek R and Torry R (1994) Growth of the coronary vasculature in hypertrophy: mechanisms and model dependence. Cell. Mol. Biol. Res. 40: $129-136$

42. Sabbah H, Sharov V and Goldstein S (1998) Programmed cell death in the progression of heart failure. Ann. Med. 30 Suppl 1: 33-38

43. Bialik S, Geenen D, Sasson I, Cheng R, Horner J, Evans S, Lord E, Koch C and Kitsis R (1997) Myocyte apoptosis during acute myocardial infarction in the mouse localizes to hypoxic regions but occurs independently of p53. J. Clin. Invest. 100: 1363-1372

44. Chakrabarti S, Hoque A and Karmazyn M (1997) A rapid ischemia-induced apoptosis in isolated rat hearts and its attenuation by the sodium-hydrogen exchange inhibitor HOE 642 (cariporide). J. Mol. Cell. Cardiol. 29: 3169-3174

45. Akiyama K, Gluckman T, Terhakopian A, Jinadasa P, Narayan S, Singaswamy S, Massey III B and Bing R (1997) Apoptosis in experimental myocardial infarction in situ and in the perfused heart in vivo. Tissue Cell 29: 733-743

46. BlackS, Huang J, Rezaiefar P, Radinovic S, Eberhart A, Nicholson D and Rodger I (1998) Co-localization of the cysteine protease caspase-3 with apoptotic myocytes after in vivomyocardial ischemia and reperfusion in the rat. J. Mol. Cell. Cardiol. 30: 733-742

47. Krown K, Page M, Nguyen C, Zechner D, Gutierrez V, Comstock K, Glembotski CC, Quintana P and Sabbadini R (1996) Tumor necrosis factor alpha-induced apoptosis in cardiac myocytes. Involvement of the sphingolipid signaling cascade in cardiac cell death. J. Clin. Invest. 98: 2854-2865

48. Kajstura J, Cigola E, Malhotra A, Li P, Cheng W, Meggs L and Anversa P (1997) Angiotensin II induces apoptosis of adult ventricular myocytes in vivo. J. Mol. Cell. Cardiol. 29: 859-870

49. Wang Y, Huang S, Sah VP, Ross Jr J, Brown JH, Han J and Chien KR (1998) Cardiac muscle cell hypertrophy and apoptosis induced by distinct members of the p38 mitogen-activated protein kinase family. J. Biol. Chem. 273:2161-2168

50. Chien KR, Knowlton KU, Zhu H and Chien S (1991) Regulation of cardiac gene expression during myocardial growth and hypertrophy: molecular studies of an adaptive physiologic response. FASEB J. 5: 3037-3046

51. Yamazaki T, Komuro I and Yazaki Y (1995) Molecular mechanism of cardiac cellular hypertrophy by mechanical stress. J. Mol. Cell. Cardiol. 27: 133-140 
52. Zimmer HG (1997) Catecholamine-induced cardiac hypertrophy: significance of protooncogene expression. J. Mol. Med. 75: 849-859

53. Tone E, Kunisada K, Fujio Y, Matsui $\mathrm{H}$, Negoro S, Oh $\mathrm{H}$, Kishimoto $\mathrm{T}$ and Yamauchi-Takihara K (1998) Angiotensin II interferes with leukemia inhibitory factor-induced STAT3 activation in cardiac myocytes. Biochem. Biophys. Res. Commun. 253: 147-150

54. Hirota H, Chen J, Betz UA, Rajewsky K, Gu Y, Ross Jr J, Muller W and Chien KR (1999) Loss of a gp 130 cardiac muscle cell survival pathway is a critical event in the onset of heart failure during biomechanical stress. Cell 97: 189-198

55. Dorn II GW and Brown JH (1999) Gq signaling in cardiac adaptation and maladaptation. Trends Cardiovasc. Med. 9: 26-34
56. Liu Q, Yan H, Dawes NJ, Mottino GA, Frank JS and Zhu H (1996) Insulin-like growth factor II induces DNA synthesis in fetal ventricular myocytes in vivo. Circ. Res. 79: 716-726

57. Thornberry NA, Rano TA, Peterson EP, Rasper DM, Timkey T, Garcia-Calvo M, Houtzager VM, Nordstrom PA, Roy S, Vaillancourt JP, Chapman KT and Nicholson DW (1997) A combinatorial approach defines specificities of members of the caspase family and granzyme B. Functional relationships established for key mediators of apoptosis. J. Biol. Chem. 272: 17907-17911 